\title{
Modulation of jasmonic acid and polyamines by 24- epibrassinolide in Brassica juncea L. under copper stress
}

\author{
Harpreet Kaur $^{1, *}$, Renu Bhardwaj ${ }^{1}$ and Ashwani Kumar Thukral ${ }^{1}$ \\ ${ }^{I}$ Department of Botanical and Environmental Sciences, Guru Nanak Dev University, Amritsar-143005, Punjab, \\ India
}

\begin{abstract}
It has been widely reported in literature that brassinosteroids play a pivotal role in stress mitigation in plants. The present study was undertaken to assess the effect of 24-epibrassinolide (24-EpiBR) on the growth, endogenous levels of total sugars, reducing sugars and plant growth regulators (PGRs) such as jasmonic acid and polyamines (PAs) like spermine, spermidine, putrescine and cadaverine in 30-day old Brassica juncea L. plants raised from seeds pre-soaked with the hormone and grown in soils amended with 0 , $0.25,0.50$ and $0.75 \mathrm{mM}$ concentrations of $\mathrm{Cu}(\mathrm{II})$. The shoot and root lengths of the plants grown in $\mathrm{Cu}(\mathrm{II})$ amended soils improved on seed pre-soaking with 24-EpiBR. The elevated levels of jasmonic acid which had a negative influence on the growth of plants under $C u(I I)$ stress were brought to normal values by 24-EpiBR treatment. 24-EpiBR showed a positive effect on the endogenous levels of total sugars, reducing sugars and PAs under $\mathrm{Cu}(I I)$ stress. Sugars help in the maintenance of osmoregulation and PAs serve as antioxidants. Thus, our results confirm the hypothesis that the exogenous application of 24-EpiBR makes the plants more capable to survive under $\mathrm{Cu}(\mathrm{II})$ stress.
\end{abstract}

Keywords: 24-epibrassinolide, copper, sugars, liquid chromatography mass spectrophotometer, plant growth regulators, jasmonic acid, polyamines

\section{Introduction}

$\mathrm{Cu}$ is a heavy metal and is required in trace amounts for normal plant growth and development. In a cell, Cu plays important role in protein trafficking machinery, iron mobilization, oxidative phosphorylation and transcription signalling. But when present in excess, $\mathrm{Cu}$ shows phytotoxicity and alters the enzyme activities and functions of proteins [1]. Metals may result in the loss of protein function due to the disruption of its structure by binding to the sulfhydryl groups present in the protein [2]. $\mathrm{Cu}$ adversely affects the process of photosynthesis by substituting the $\mathrm{Mg}$ in the chlorophyll present in both the reaction centres and antenna complexes, which results in the loss of chlorophyll structure and function. Excess $\mathrm{Cu}$ produces oxidative stress by increasing the content of reactive oxygen species (ROS) such as $\mathrm{H}_{2} \mathrm{O}_{2}, \mathrm{O}_{2}{ }^{-}$and $\mathrm{OH}$, which affect carbohydrates, nucleic acids, proteins and lipids [3]. $\mathrm{H}_{2} \mathrm{O}_{2}$ produced by heavy metal stress causes lipid peroxidation resulting in the disintegration of biomembranes [4].

Plants combat the damaging effects of stress by modulating the endogenous levels of various biomolecules such as antioxidant enzymes, sugars and growth regulators like PAs and jasmonic acid. Recent studies have shown a significant role of plant growth regulators (PGRs) such as abscisic acid, gibberellins, auxins, cytokinins, PAs and BRs in the mitigation of abiotic stress [5,6,7]. BRs are steroidal hormones and play role in a number of physiological processes such as epinasty, leaf bending, photosynthesis, xylem differentiation, activation of proton-pump and stem elongation. They provide tolerance to plants against different types of stresses for e.g. heavy metals, temperature, salinity, drought, pesticides and pathogens attack [8]. BRs also mitigate plant stress by interaction with other PGRs such as abscisic acid, auxins, PAs and gibberellins [9].

Jasmonic acid is an important component of signalling pathways initiated in plants after a number of biotic and abiotic stresses and enhances the resistance of plants under these stresses. Heavy metals can affect plants directly or indirectly through the initiation of signalling pathways involving jasmonic acid. The increased levels of these signalling substances, increase plant resistance to stress.

PAs are aliphatic phytohormones including putrescine, spermidine, spermine and cadaverine with two or more primary amino groups. They are ubiquitous but their amount varies according to the environmental conditions. As they are involved in a variety of processes which increase stress tolerance of plants, an enhancement in their amount has been reported under wide array of abiotic stress conditions [10,11]. Enhancement in the content of PAs under stress conditions helps the plants in adapting to environmental stresses by maintaining the integrity of biomembranes; regulating the ionic environment of cells; preventing the loss of chlorophyll; stimulating protective alkaloids, nucleic acids and proteins. Their cationic nature enables them to covalently bind with proteins, DNA, RNA and components of cell wall and so affect the synthesis, function and 
structure of these macromolecules $[12,13]$. They regulate a number of cellular processes such as replication, transcription and translation of DNA; cell division; cation-anion balance of cell and modulate enzyme activities. The present study aims to determine the effect of 24-EpiBR on shoot length, root length and endogenous levels of jasmonic acid and PAs such as putrescine, spermidine, spermine and cadaverine, and sugars in $B$. juncea plants under $\mathrm{Cu}$ (II) stress. We also focussed on that how the modulation of the amount of these molecules by $\mathrm{Cu}(\mathrm{II})$ and 24-EpiBR influenced their interaction with one another.

\section{Materials and methods}

Certified seeds of $B$. juncea used in the present work were procured from Punjab Agricultural University, Punjab, India. Seeds were surface sterilized and then were given pre-soaking treatment with different concentrations of 24-EpiBR $(0,0.01,1$ and $100 \mathrm{nM})$. The seeds were then sown in a field prepared according to randomized block design. The soil of the field was treated with different concentrations of $\mathrm{Cu}(\mathrm{II})$ $(0,0.25,0.50$ and $0.75 \mathrm{mM})$. Plants were harvested after 30 days of the sowing.

\subsection{Growth parameters}

Shoot and root lengths of the harvested plants were measured.

\subsection{Estimation of endogenous content of jasmonic acid and PAs}

The endogenous contents of PGRs were estimated by using Agilent 6410 Triple-Quad liquid chromatography mass spectrophotometer (LCMS). Sample preparation: Homogenisation of $0.50 \mathrm{~g}$ of leaves of B. juncea plants was done in $5 \mathrm{ml}$ of methanol (80\%). The extract was subjected to centrifugation. The supernatant was collected and filtered using nylon filter membrane of pore size 0.22 microns. The filtrate so obtained was used to measure the endogenous contents of jasmonic acid and PAs such as putrescine, spermidine, spermine and cadaverine using LCMS.

LCMS analysis: For the LCMS analysis we used the conditions employed by Banerjee and Kulkarni [14]. $2 \mu \mathrm{l}$ of the above filtrate was injected for LCMS analysis. Mobile phase A was water (0.5\% formic acid) and mobile phase B was methanol. Column temperature was $40{ }^{\circ} \mathrm{C}$. Run time was 16 min in positive mode and 6 min in negative mode. Flow rate was $200 \mu 1 / m i n$.

\subsection{Estimation of sugars}

Sugars were estimated by using spectrophotometer thermo electron corporation, Genesys 10UV.

Extraction: Extraction of the plant leaves was done with ethanol in boiling water bath. The extracts were reduced to aqueous syrup by evaporation of the solvent using rotary vacuum evaporator. Volume of the aqueous syrup was raised to $100 \mathrm{ml}$ with distilled water.

\subsubsection{Estimation of total sugars}

The endogenous content of total sugars was measured using the method of Dubois et al. [15]. 5\% of phenol and $5 \mathrm{ml}$ of conc. $\mathrm{H}_{2} \mathrm{SO}_{4}$ were added to the test extract. Absorbance was measured at $490 \mathrm{~nm}$ against blank. A standard curve prepared using glucose standards was used to measure the concentration of total sugars.

\subsubsection{Estimation of reducing sugars}

For the determination of the endogenous content of reducing sugars, method of Nelson [16] was employed. Five reagents as required for the experiment were prepared. Reagent A: Sodium carbonate, anhydrous sodium sulphate, sodium bicarbonate and potassium sodium tartarate were dissolved in $100 \mathrm{ml}$ of distilled water. Reagent B: Dissolved $\mathrm{CuSO}_{4} .5 \mathrm{H}_{2} \mathrm{O}$ in $4 \mathrm{ml}$ of distilled water. After it conc. $\mathrm{H}_{2} \mathrm{SO}_{4}$ was added. Reagent C: For it reagents A and B were mixed in a ratio of 25:1. Reagent D: It was prepared by dissolving ammonium molybdate in $50 \mathrm{ml}$ of distilled water, followed by the addition of $2.3 \mathrm{ml}$ of conc. $\mathrm{H}_{2} \mathrm{SO}_{4}$. To this mixture was added the solution of sodium arsenate in distilled water. Procedure: To the test extracts, $1 \mathrm{ml}$ of reagent $\mathrm{C}$ was added. The resulting mixture was heated in boiling water bath followed by addition of $1 \mathrm{ml}$ of reagent $\mathrm{D}$ and the volume was raised to $10 \mathrm{ml}$. Absorbance was taken at $520 \mathrm{~nm}$ against blank. A standard curve prepared using glucose standards was used to determine the concentration of the reducing sugars.

\subsection{Statistical Analysis}

Self coding software was used for the statistical analysis of the data. The data was presented as mean \pm standard deviation. Two way analysis of variance (ANOVA) was carried out and HSD was determined by using Tukey's multiple comparison test. The data was considered significant at $\mathrm{P} \leq 0.05$. Multiple regression with interaction were applied on the data. \% variability explained was calculated. 


\subsection{Shoot length}

\section{Results}

A decline was observed in the shoot length per plant with increase in the concentration of $\mathrm{Cu}(\mathrm{II})$ solutions applied in soil. In comparison to the control $(6.71 \mathrm{~cm})$, maximum decline $(-76.0 \%)$ was observed in plants grown in soil applied with $0.75 \mathrm{mM} \mathrm{Cu}(\mathrm{II})(1.61 \mathrm{~cm})$. Among the binary combinations of 24-EpiBR and $\mathrm{Cu}$ (II), plants raised from $100 \mathrm{nM} 24$-EpiBR and grown in soil applied with $0.75 \mathrm{mM} \mathrm{Cu}(\mathrm{II})$ showed maximum improvement $(3.11 \mathrm{~cm}, 93.2 \%)$ in the shoot length (Table 1). $\mathrm{Cu}(\mathrm{II}), 24-\mathrm{EpiBR}$ as well as their binary combinations ( $\mathrm{Cu}(\mathrm{II}) \times 24-\mathrm{EpiBR})$ had F-ratios significant at $\mathrm{P}<0.01$ (Table 1). HSD was $0.33 \mathrm{~cm}$. As compared to the control, the plants grown in $\mathrm{Cu}$ (II) applied soil showed significant decline in the shoot length. Among the binary combinations, maximum improvement was caused by the combination of $100 \mathrm{~nm} 24$-EpiBR and 0.75 $\mathrm{mM} \mathrm{Cu}(\mathrm{II})$ in comparison to the respective $\mathrm{Cu}(\mathrm{II})(0.75 \mathrm{mM})$ alone treatment (Table 1$)$. The data was analysed with multiple regression with interaction. The values for $\mathrm{Cu}$ (II) (-0.93) and 24-EpiBR (0.19) showed that $\mathrm{Cu}$ (II) treatment to soil declined the shoot length, whereas 24-EpiBR seed pre-soaking treatment positively affected the shoot length. $\beta$-regression (-0.06) for $\mathrm{Cu}(\mathrm{II}) \times 24$-EpiBR showed slightly negative interaction between $\mathrm{Cu}(\mathrm{II})$ and 24-EpiBR (Table 1). Cu(II), 24-EpiBR and their interaction explained $92.64 \%$ variability (Table 1 ).

\subsection{Root length}

$\mathrm{Cu}$ (II) treatment to the soil decreased the root length per plant. When compared with the control (5.15 $\mathrm{cm})$, maximum decline $(-74 \%)$ in the root length was caused by $0.75 \mathrm{mM} \mathrm{Cu}(\mathrm{II})(1.34 \mathrm{~cm})$ treatment to the soil. 24-EpiBR seed pre-soaking treatment improved root length in the plants grown under $\mathrm{Cu}$ (II) stress. Plants given the seeds pre-soaking treatment with $1 \mathrm{nM} 24-E p i B R$ and grown in the soil applied with $0.75 \mathrm{mM} \mathrm{Cu}(\mathrm{II})$ solution, showed maximum improvement $(2.83 \mathrm{~cm}, 111.2 \%)$ in the root length (Table 2). $\mathrm{Cu}(\mathrm{II}), 24-\mathrm{EpiBR}$ and $\mathrm{Cu}$ (II) $\mathrm{x}$ 24-EpiBR had F-ratios significant at $\mathrm{p}<0.01$ (Table 2). HSD was $0.25 \mathrm{~cm}$. When compared with the control, soil treatment with different concentrations of $\mathrm{Cu}(\mathrm{II})(0.25,0.50$ and $0.75 \mathrm{mM})$ caused significant decline in the root length. Binary combination of $1 \mathrm{nM} 24$-EpiBR and $0.75 \mathrm{mM} \mathrm{Cu}$ (II) showed maximum improvement in the root length (Table 2). The data was analysed with multiple regression with interaction. Highly negative $\beta$-regression (-0.93) for $\mathrm{Cu}(\mathrm{II})$ revealed much inhibitory effect of $\mathrm{Cu}$ (II) on the root length. $\beta$ regression for 24-EpiBR (0.19) showed its positive effect on the root length. $\beta$-regression (-0.05) for $\mathrm{Cu}$ (II) $\mathrm{x}$ 24-EpiBR showed that there was slight negative interaction between $\mathrm{Cu}(\mathrm{II})$ and 24-EpiBR (Table 2). $\mathrm{Cu}(\mathrm{II}), 24-$ EpiBR and their interaction explained $91.68 \%$ variability (Table 2).

\subsection{Jasmonic acid}

Plants grown in the soil treated with $0.50 \mathrm{mM} \mathrm{Cu}(\mathrm{II})$ showed an enhancement $(59.1 \%)$ in the jasmonic acid content (relative abundance: 805.20) in their leaves as compared to the control (relative abundance: 506.10). $100 \mathrm{nM}$ 24-EpiBR seed pre-soaking declined (-14.6\%) the content of jasmonic acid (relative abundance: 687.80) in the leaves of plants grown in the soil applied with $0.50 \mathrm{mM} \mathrm{Cu(II)}$ solution in comparison to the $0.50 \mathrm{mM} \mathrm{Cu}(\mathrm{II})$ alone treatment (Table 3, Fig. 1). F-ratio values for $\mathrm{Cu}(\mathrm{II}), 24-\mathrm{EpiBR}$ and $\mathrm{Cu}(\mathrm{II}) \times \mathrm{24}$-EpiBR were significant at $\mathrm{P}<0.01$ (Table 3). HSD for relative abundance was 39.04. When compared with the control, $0.50 \mathrm{mM} \mathrm{Cu}$ (II) solution treatment to the soil caused significant increase in the content of jasmonic acid in leaves of the plants. Plants raised from the seeds pre-soaked with $100 \mathrm{nM} 24-\mathrm{EpiBR}$ and grown in the soil treated with solution of $0.50 \mathrm{mM} \mathrm{Cu}(\mathrm{II})$, showed significant decline in the content of jasmonic acid as compared to soil $0.50 \mathrm{mM} \mathrm{Cu}$ (II) alone treatment (Table 3). The data was subjected to analysis with multiple regression with interaction. $\beta$-regression values for $\mathrm{Cu}(\mathrm{II})(1.09)$ and 24-EpiBR (-0.13) indicated that the jasmonic acid content increased in the leaves of plants grown in $\mathrm{Cu}(\mathrm{II})$ applied soil while decreased in the leaves of plants raised from the seeds pre-soaked in 24-EpiBR. $\beta$-regression value for $\mathrm{Cu}$ (II) x 24-EpiBR (0.26) implied negative interaction between $\mathrm{Cu}(\mathrm{II})$ and 24-EpiBR (Table 3). $\mathrm{Cu}(\mathrm{II}), 24-\mathrm{EpiBR}$ and their interaction explained $98.94 \%$ variability (Table 3).

\subsection{PAs}

\subsubsection{Spermine}

Spermine content (relative abundance: 251.10 ) enhanced (115.9\%) in the leaves of $B$. juncea plants grown in the soil applied with $0.50 \mathrm{mM} \mathrm{Cu}(\mathrm{II})$ in comparison to the control (relative abundance: 116.30). A further enhancement of $131.7 \%$ was observed in the spermine content (relative abundance: 581.90 ) in the leaves of plants raised from the seeds given pre-soaking treatment of $100 \mathrm{nM} 24-E p i B R$ and grown in the soil amended with $0.50 \mathrm{mM} \mathrm{Cu}(\mathrm{II})$ (Table 4, Fig. 2). $\mathrm{Cu}(\mathrm{II}), 24-E p i B R$ and $\mathrm{Cu}(\mathrm{II}) \times$ 24-EpiBR had F-ratios significant at $\mathrm{P}<0.01$ (Table 4). HSD was 28.29 (relative abundance). A significant increase in the content of spermine was observed in the leaves of the plants grown in the soil amended with $0.50 \mathrm{mM} \mathrm{Cu}$ (II) solution. Plants raised from the seeds pre-soaked with $100 \mathrm{nM}$ 24-EpiBR and grown in the soil treated with $0.50 \mathrm{mM} \mathrm{Cu}(\mathrm{II})$ solution, showed significant enhancement in the content of spermine in their leaves as compared to leaves of the plants 
given soil $0.50 \mathrm{mM} \mathrm{Cu}(\mathrm{II})$ alone treatment (Table 4). The data was subjected to analysis with multiple regression with interaction. $\beta$-regression for $\mathrm{Cu}(\mathrm{II})(0.36)$ indicated that the soil $\mathrm{Cu}(\mathrm{II})$ treatment increased the spermine content. $\beta$-regression for 24-EpiBR (0.03) implied that 24-EpiBR seed pre-soaking treatment also induced increase in the content of spermine but to a lesser extent. The interaction between $\mathrm{Cu}(\mathrm{II})$ and 24-EpiBR was positive as evident from the $\beta$-regression value (0.74) for $\mathrm{Cu}$ (II) x 24-EpiBR (Table 4). 99.70\% variability was explained by $\mathrm{Cu}(\mathrm{II}), 24-\mathrm{EpiBR}$ and their interaction (Table 4).

\subsubsection{Spermidine}

Spermidine content (relative abundance: 200.50) increased (89.7\%) in the leaves of plants grown in $0.50 \mathrm{mM} \mathrm{Cu}(\mathrm{II})$ applied soil in comparison to the control (relative abundance: 105.70). Plants raised from the seeds given pre-soaking treatment with $100 \mathrm{nM} 24-\mathrm{EpiBR}$ and grown in the soil amended with $0.50 \mathrm{mM} \mathrm{Cu}(\mathrm{II})$, showed a further enhancement (89.3\%) in the spermidine content (relative abundance: 379.60 ) in their leaves (Table 5, Fig. 3). $\mathrm{Cu}(\mathrm{II}), 24-\mathrm{EpiBR}$ and $\mathrm{Cu}(\mathrm{II}) \mathrm{x}$ 24-EpiBR had F-ratio values significant at $\mathrm{P}<0.01$ (Table 5). HSD was 32.01 (relative abundance). When compared with the control, spermidine content increased significantly in leaves of the plants grown in the soil treated with $0.50 \mathrm{mM} \mathrm{Cu}$ (II) solution. Binary combination of $100 \mathrm{nM}$ 24-EpiBR and $0.50 \mathrm{mM} \mathrm{Cu}(\mathrm{II})$ caused significant enhancement in the spermidine content when compared with the soil $0.50 \mathrm{mM} \mathrm{Cu}(\mathrm{II})$ alone treatment (Table 5). The data was analysed with multiple regression with interaction. $\mathrm{Cu}(\mathrm{II})$ and 24-EpiBR induced positive effect on the spermidine content as evident from their $\beta$-regression values, 0.45 and 0.17 , respectively. B-regression for $\mathrm{Cu}(\mathrm{II}) \times 24-\mathrm{EpiBR}(0.59)$ revealed positive interaction between $\mathrm{Cu}(\mathrm{II})$ and 24-EpiBR (Table 5). $1 \%$ variability was explained by $\mathrm{Cu}(\mathrm{II}), 24-\mathrm{EpiBR}$ and their interaction (Table 5).

\subsubsection{Putrescine}

As compared to the control (relative abundance: 922.10$)$ an increase (47\%) was observed in the relative abundance (1355.70) of putrescine in leaves of the plants grown in the soil treated with $0.50 \mathrm{mM} \mathrm{Cu}(\mathrm{II})$. Putrescine content (relative abundance: 1966.30) increased (45\%) further in leaves of the plants raised from the seeds given pre-soaking treatment with $100 \mathrm{nM}$ 24-EpiBR and grown in the soil treated with $0.50 \mathrm{mM} \mathrm{Cu}(\mathrm{II})$ (Table 6, Fig. 4). F-ratio values for $\mathrm{Cu}(\mathrm{II})$ and 24-EpiBR were significant at $\mathrm{P}<0.01$, whereas F-ratio value for $\mathrm{Cu}(\mathrm{II}) \times$ 24-EpiBR was significant at $\mathrm{P}<0.05$ (Table 6). HSD was 311.83 (relative abundance). Putrescine content increased significantly in leaves of the plants grown in the soil treated with $0.50 \mathrm{mM} \mathrm{Cu}$ (II) solution as compared to the control. As compared to the $0.50 \mathrm{mM} \mathrm{Cu}(\mathrm{II})$ alone treatment, the binary combination of 100 $\mathrm{nM}$ 24-EpiBR and $0.50 \mathrm{mM} \mathrm{Cu}$ (II) caused significant enhancement in the content of putrescine in the plant leaves (Table 6). The data was subjected to multiple regression with interaction. $\beta$-regression values for $\mathrm{Cu}(\mathrm{II})$ and 24-EpiBR, 0.54 and 0.27 , respectively, indicated that both soil $\mathrm{Cu}(\mathrm{II})$ treatment as well as 24-EpiBR seed pre-soaking treatment enhanced the content of putrescine in leaves of the plants. $\beta$-regression value for $\mathrm{Cu}(\mathrm{II}) \mathrm{x}$ 24-EpiBR (0.42) indicated that $\mathrm{Cu}(\mathrm{II})$ and 24-EpiBR interacted positively (Table 6). $\mathrm{Cu}(\mathrm{II}), 24-\mathrm{EpiBR}$ and their interaction explained $92.29 \%$ variability (Table 6).

\subsubsection{Cadaverine}

Treatment of soil with $0.50 \mathrm{mM} \mathrm{Cu}$ elevated $(119.2 \%)$ the cadaverine content (relative abundance: 3439.50) in the leaves of plants as compared to the control (relative abundance: 1568.90). Cadaverine content further enhanced (50.0\%) in leaves of the plants raised from the seeds given pre-soaking treatment with $100 \mathrm{nM}$ 24-EpiBR and grown in the soil applied with $0.50 \mathrm{mM} \mathrm{Cu}$ (II) (relative abundance: 5177) (Table 7, Fig. 5). $\mathrm{Cu}$ (II) and 24-EpiBR treatments, separately as well as in combination had F-ratio values significant at $\mathrm{P}<0.01$ (Table 7). HSD was 279.10 (relative abundance). In comparison to the control, cadaverine content increased significantly in leaves of the plants grown in soil treated with $0.50 \mathrm{mM} \mathrm{Cu}(\mathrm{II})$ solution. Binary combination of $100 \mathrm{nM}$ 24-EpiBR and $0.50 \mathrm{mM} \mathrm{Cu}$ (II) caused significant enhancement in the content of cadaverine as compared to the $0.50 \mathrm{mM} \mathrm{Cu}$ (II) alone treatment (Table 7). The data was subjected to analysis with multiple regression with interaction. The soil treatment with $\mathrm{Cu}$ (II) solution caused elevation in the cadaverine content as indicated by the $\beta$-regression value (0.63) for $\mathrm{Cu}(\mathrm{II})$. 24-EpiBR seed pre-soaking treatment also induced some positive effect on the cadaverine content, as observed from the $\beta$-regression (0.02) for 24-EpiBR. $\beta$-regression (0.48) for $\mathrm{Cu}(\mathrm{II}) \times 24-\mathrm{EpiBR}$ showed positive interaction between $\mathrm{Cu}(\mathrm{II})$ and 24-EpiBR (Table 7). 99.54\% variability was explained by $\mathrm{Cu}(\mathrm{II}), 24-\mathrm{EpiBR}$ and their interaction (Table 7).

\subsection{Sugars}

\subsubsection{Total sugars}

Increase in the concentration of $\mathrm{Cu}(\mathrm{II})$ solution applied to the soil increased the content of total sugars in the leaves of plants. Maximum increase (79.4\%) in the content of total sugars (2.44 $\mathrm{mg} \mathrm{g}^{-1} \mathrm{FW}$ ) was observed in leaves of the plants grown in the soil treated with $0.75 \mathrm{mM} \mathrm{Cu}$ (II) as compared to the control $\left(1.36 \mathrm{mg} \mathrm{g}^{-1}\right.$ FW). Leaves of the plants raised from the seeds given pre-soaking treatment with 24-EpiBR and grown in the 
soil treated with $\mathrm{Cu}(\mathrm{II})$, showed further increase in the content of total sugars. Binary combination of $100 \mathrm{nM}$ 24-EpiBR and $0.50 \mathrm{mM} \mathrm{Cu}(\mathrm{II})$, showed maximum enhancement $\left(2.89 \mathrm{mg} \mathrm{g}^{-1} \mathrm{FW}, 36.3 \%\right)$ in the content of total sugars as compared to the soil $0.50 \mathrm{mM} \mathrm{Cu}$ (II) alone treatment (2.12 $\mathrm{mg} \mathrm{g}^{-1} \mathrm{FW}$ ) (Table 8). $\mathrm{Cu}$ (II), 24-EpiBR and $\mathrm{Cu}(\mathrm{II}) \times$ 24-EpiBR had F-ratios significant at $\mathrm{P}<0.01$ (Table 8). HSD was $0.10 \mathrm{mg} \mathrm{g}^{-1} \mathrm{FW}$. $\mathrm{Cu}$ (II) treatment to the soil caused significant decline in the content of total sugars in the leaves of $B$. juncea plants when compared with the control. Binary combination of $100 \mathrm{nM} 24-\mathrm{EpiBR}$ and $0.50 \mathrm{mM} \mathrm{Cu}$ (II) caused maximum enhancement in the content of total sugars in comparison to the respective $\mathrm{Cu}(\mathrm{II})(0.50 \mathrm{mM})$ alone treatment (Table 8). Multiple regression with interaction analysis was applied on the data. $\beta$-regression values for $\mathrm{Cu}$ (II) and 24-EpiBR, 0.84 and 0.19, respectively, implied that both of the treatments enhanced the content of total sugars. $\beta$-regression for $\mathrm{Cu}(\mathrm{II}) \mathrm{x}$ 24-EpiBR (0.13) indicated positive interaction between $\mathrm{Cu}(\mathrm{II})$ and 24-EpiBR (Table 8 ). $87.39 \%$ variability was explained by $\mathrm{Cu}(\mathrm{II}), 24-\mathrm{EpiBR}$ and their interaction (Table 8 ).

\subsubsection{Reducing sugars}

Reducing sugars enhanced in the leaves of plants given soil $\mathrm{Cu}(\mathrm{II})$ stress in comparison to the control $\left(1.16 \mathrm{mg} \mathrm{g}^{-1} \mathrm{FW}\right)$, with maximum enhancement of $20.7 \%$ observed under the stress of $0.75 \mathrm{mM} \mathrm{Cu}$ (II) $(1.40 \mathrm{mg}$ $\mathrm{g}^{-1} \mathrm{FW}$ ). Seed pre-soaking treatment with 24-EpiBR further increased the content of reducing sugars in the leaves of plants. Seed pre-soaking with $100 \mathrm{nM}$ 24-EpiBR resulted in maximum enhancement (17.1\%) in the content of reducing sugars $\left(1.51 \mathrm{mg} \mathrm{g}^{-1} \mathrm{FW}\right)$ under $0.25 \mathrm{mM} \mathrm{Cu}(\mathrm{II})$ soil stress when compared with the respective $\mathrm{Cu}$ (II) $(0.25 \mathrm{mM})$ alone treatment $\left(1.29 \mathrm{mg} \mathrm{g}^{-1} \mathrm{FW}\right.$ ) (Table 9). F-ratios for $\mathrm{Cu}$ (II) and 24-EpiBR were significant at $\mathrm{P}<0.01$, whereas F-ratio for $\mathrm{Cu}$ (II) $\mathrm{x}$ 24-EpiBR was not significant (Table 9). HSD was $0.08 \mathrm{mg} \mathrm{g}^{-1} \mathrm{FW}$. When compared with the control, the content of reducing sugars showed significant decrease in the leaves of plants grown in the soil treated with different concentrations of $\mathrm{Cu}(\mathrm{II})(0.25,0.50$ and $0.75 \mathrm{mM})$. Binary combination of 100 $\mathrm{nM}$ 24-EpiBR and $0.25 \mathrm{mM} \mathrm{Cu}(\mathrm{II})$ resulted in maximum enhancement in the content of reducing sugars in comparison to the plants grown in the $0.25 \mathrm{mM} \mathrm{Cu}$ (II) applied soil but without 24-EpiBR seed pre-soaking treatment (Table 9). The data was analysed with multiple regression with interaction. $\beta$-regression for $\mathrm{Cu}(\mathrm{II})(0.61)$ revealed that $\mathrm{Cu}(\mathrm{II})$ stress increased the reducing sugars content. $\beta$-regression for 24-EpiBR (0.39) implied that 24-EpiBR also had some positive effect on the reducing sugars content. The value of $\beta$-regression (0.12) for $\mathrm{Cu}(\mathrm{II}) \times 24-\mathrm{EpiBR}$ indicated positive interaction between $\mathrm{Cu}$ (II) and 24-EpiBR (Table 9). 65.17\% variability was explained by $\mathrm{Cu}(\mathrm{II})$, 24-EpiBR and their interaction (Table 9).

\section{Discussion}

The decrease in the shoot and root lengths of the plants under $\mathrm{Cu}(\mathrm{II})$ stress might be due to the increased content of $\mathrm{Cu}(\mathrm{II})$ in the plant tissues, which adversely affected the plant metabolism. $\mathrm{Cu}$ stress generates $\mathrm{H}_{2} \mathrm{O}_{2}$ which cross links the polymers of cell wall, due to it cell wall becomes non-elastic [17]. Nonelasticity of cell walls reduced their elongation. It might be the reason for the observed decrease in the shoot and root lengths of the $B$. juncea plants grown in the soil treated with $\mathrm{Cu}$ (II) solution. Improvement in the plant growth due to 24-EpiBR seed pre-soaking might be due to its stimulatory effect on genes encoding for expansins and xyloglucanses [18].

Detoxification of heavy metals by PGRs is a widely accepted concept. To overcome the toxic effects of stress produced by heavy metals, there occurs production of a number of PGRs in plants. To test this hypothesis, we determined the endogenous levels of jasmonic acid and four types of PAs: spermine, spermidine, putrescine and cadaverine in $B$. juncea plants given the treatment of $\mathrm{Cu}(\mathrm{II})$ and 24-EpiBR alone and in combination. Jasmonic acid and its derivatives are the components of signalling pathways and are biosynthesized in plants in response to various biotic and abiotic stress conditions such as heavy metal stress, pathogen attack, wounding etc. $[19,20]$. Jasmonic acid helps in ROS detoxification by stimulating the production of various secondary metabolites like coumarins, ascorbic acid and flavonoids, and antioxidant enzymes like glutathione reductase, catalase etc. Jasmonic acid activity is also related with reduction in the activity of photosynthetic apparatus $[21,22]$ and the reduction in growth [23,24]. Heavy metals such as $\mathrm{Cu}$ cause disturbance in the membrane structure and increases the concentration of $\mathrm{H}_{2} \mathrm{O}_{2}$. Peroxidative processes produce substrates for the synthesis of jasmonic acid through octadecanoid pathways. In the results of present study also, jasmonic acid content increased in plants grown in $\mathrm{Cu}(\mathrm{II})$ treated soil in a dose dependent manner and there was a concomitant decrease in shoot and root lengths. It suggests a relationship between jasmonic acid level in plant and the plant growth. Increase in the levels of jasmonic acid with increase in $\mathrm{Cu}(\mathrm{II})$ stress resulted in a concomitant reduction in shoot and root lengths. The results are in accordance with the studies done by Rakwal et al. [25] in rice plants. They observed an increase in jasmonic acid under $\mathrm{Cu}$ stress. Our results showed reduction in the amount of jasmonic acid and improvement in shoot length and root length on supplementation of soil $\mathrm{Cu}(\mathrm{II})$ treatment with 24-EpiBR seed pre-soaking treatment. The results are supported by the work of Ren et al. [26] in Arabidopsis thaliana where they observed that the root length reduced by the jasmonic acid alone treatment, was restored on supplementation of jasmonic acid with epibrassinolide. The results of our experiments proved the hypothesis 
that the endogenous contents of various PAs rise on metal treatment. Increase in the amount of PAs (spermine, spermidine, putrescine and cadaverine) in the leaves of plants grown under $\mathrm{Cu}(\mathrm{II})$ stress helped in the mitigation of $\mathrm{Cu}$ (II) stress. Further increase in the contents of PAs on the supplementation of soil $\mathrm{Cu}$ (II) treatment with 24EpiBR seed pre-soaking treatment enhanced the $\mathrm{Cu}$ (II) stress amelioration by PAs. PAs inhibit NADPH oxidase and hinder the accumulation of $\mathrm{O}_{2}^{-}$, thus exhibit antioxidative behaviour [27]. The amino groups present in PAs undergo reversible protonation. It enhances the content of $\mathrm{H}^{+}$ions and organic acids under acidic environment. Thus metabolism of PAs helps in building a buffering mechanism for maintaining ion homeostasis and cellular $\mathrm{pH}$ [28]. PAs act as metal chelators also and reduce the movement of metal into the cells.

Total sugars and reducing sugars increased under $\mathrm{Cu}(\mathrm{II})$ stress. The results are consistent with the results of Aly and Mohamed [29], who observed an enhancement in total sugars in Zea mays under $\mathrm{Cu}(\mathrm{II})$ stress, and with Samarakoon and Rauser [30] who found that reducing sugars increased in Phaseolus vulgaris plants under Ni and $\mathrm{Zn}$ stress. Sugars play role in osmoregulation and act as storage reserves to support the basal metabolism of plants under stress [31]. In the present investigation, the binary combination of $\mathrm{Cu}(\mathrm{II})$ and 24EpiBR further increased the contents of total sugars and reducing sugars as compared to $\mathrm{Cu}(\mathrm{II})$ alone treatment. It could be due to the enhancement in photosynthetic activity due to 24-EpiBR seed pre-soaking treatment [32]. Total sugars and reducing sugars are also affected by PAs [33]. So, the enhancing effect of 24-EpiBR on the above sugars might be mediated by its stimulatory effect on PAs. The role of PAs in increasing the content of total sugars and reducing sugars through the activation of invertases and amylases under drought stress conditions has been reported by Zeid and Shedeed [34].

\section{Figures and tables}

Table 1. Effect of seed pre-soaking with 24-EpiBR on shoot length per plant $(\mathrm{cm})$ in 30-day old plants of $B$. juncea grown in soil amended with $\mathrm{Cu}(\mathrm{II})$ solution before sowing.

\begin{tabular}{|c|c|c|c|c|}
\hline Treatments & Control & $0.25 \mathrm{mM} \mathrm{Cu}(\mathrm{II})$ & $0.50 \mathrm{mM} \mathrm{Cu}(\mathrm{II})$ & $0.75 \mathrm{mM} \mathrm{Cu}(\mathrm{II})$ \\
\hline Control & $6.71 \pm 0.646$ & $5.03 \pm 0.160$ & $3.29 \pm 0.079$ & $1.61 \pm 0.316$ \\
\hline 0.01 nM 24-EpiBR & $7.71 \pm 0.135$ & $6.04 \pm 0.140$ & $4.11 \pm 0.069$ & $2.24 \pm 0.136$ \\
\hline 1 nM 24-EpiBR & $8.32 \pm 0.052$ & $6.39 \pm 0.089$ & $5.21 \pm 0.181$ & $2.85 \pm 0.443$ \\
\hline 100 nM 24-EpiBR & $8.72 \pm 0.066$ & $6.59 \pm 0.298$ & $4.27 \pm 0.220$ & $3.11 \pm 0.125$ \\
\hline \multicolumn{5}{|l|}{ Two way ANOVA } \\
\hline \multicolumn{2}{|c|}{ F-ratio $(3,32)(\mathrm{Cu})=1032.78^{* *}$} & \multicolumn{3}{|c|}{ F-ratio $(3,32)(24-E p i B R)=99.25^{* *}$} \\
\hline \multicolumn{2}{|c|}{ F-ratio $(9,32)(\mathrm{Cu} \times 24-\mathrm{EpiBR})=3.67 * *$} & \multicolumn{3}{|l|}{$\mathrm{HSD}=0.33$} \\
\hline \multicolumn{5}{|c|}{ Multiple regression with interaction } \\
\hline \multicolumn{5}{|c|}{$\mathrm{Y}=7.60-7.06(\mathrm{Cu}, \mathrm{mM})+0.01(24-\mathrm{EpiBR}, \mathrm{nM})-0.01(\mathrm{Cu} \times 24-E p i B R)$} \\
\hline \multicolumn{2}{|c|}{$\beta$-regression $(\mathrm{Cu})=-0.93$} & \multicolumn{3}{|c|}{$\beta$-regression $(24-E p i B R)=0.19$} \\
\hline \multicolumn{2}{|c|}{$\beta$-regression $(\mathrm{Cu} \times 24$-EpiBR $)=-0.06$} & \multicolumn{3}{|c|}{ Multiple correlation; $\%$ variability explained $=0.9625^{* * * ;} 92.64$} \\
\hline
\end{tabular}

Table 2. Effect of seed pre-soaking with 24-EpiBR on root length per plant $(\mathrm{cm})$ in 30-day old plants of

$B$. juncea grown in soil amended with $\mathrm{Cu}(\mathrm{II})$ solution before sowing.

\begin{tabular}{|c|c|c|c|c|}
\hline Treatments & Control & $0.25 \mathrm{mM} \mathrm{Cu}(\mathrm{II})$ & $0.50 \mathrm{mM} \mathrm{Cu}(\mathrm{II})$ & $0.75 \mathrm{mM} \mathrm{Cu}(\mathrm{II})$ \\
\hline Control & $5.15 \pm 0.203$ & $3.91 \pm 0.164$ & $2.63 \pm 0.377$ & $1.34 \pm 0.145$ \\
\hline 0.01nM 24-EpiBR & $6.19 \pm 0.101$ & $4.63 \pm 0.151$ & $3.21 \pm 0.121$ & $1.89 \pm 0.361$ \\
\hline 1 nM 24-EpiBR & $6.68 \pm 0.098$ & $5.04 \pm 0.098$ & $3.39 \pm 0.176$ & $2.83 \pm 0.111$ \\
\hline 100 nM 24-EpiBR & $6.7 \pm 0.164$ & $5.08 \pm 0.187$ & $3.82 \pm 0.130$ & $2.34 \pm 0.204$ \\
\hline \multicolumn{5}{|l|}{ Two way ANOVA } \\
\hline \multicolumn{3}{|c|}{ F-ratio $(3,32)(\mathrm{Cu})=1007.79 * *$} & \multicolumn{2}{|c|}{ F-ratio $(3,32)(24$-EpiBR $)=109.16^{* *}$} \\
\hline \multicolumn{3}{|c|}{ F-ratio $(9,32)(\mathrm{Cu} \times 24$-EpiBR $)=3.26^{* *}$} & \multicolumn{2}{|l|}{$\mathrm{HSD}=0.25$} \\
\hline \multicolumn{5}{|c|}{ Multiple regression with interaction } \\
\hline \multicolumn{5}{|c|}{$\mathrm{Y}=5.91-5.36(\mathrm{Cu}, \mathrm{mM})+0.01(24-\mathrm{EpiBR}, \mathrm{nM})-0.004(\mathrm{Cu} \times 24-\mathrm{EpiBR})$} \\
\hline \multicolumn{3}{|c|}{$\beta$-regression $(\mathrm{Cu})=-0.93$} & \multicolumn{2}{|c|}{$\beta$-regression $(24-E p i B R)=0.19$} \\
\hline \multicolumn{3}{|c|}{$\beta$-regression $(\mathrm{Cu} \times 24-\mathrm{EpiBR})=-0.05$} & \multicolumn{2}{|c|}{$\begin{array}{l}\text { Multiple correlation; } \% \text { variability explained = } \\
0.9575^{* * * ;} ; 1.68\end{array}$} \\
\hline
\end{tabular}

Table 3. Effect of seed pre-soaking with 24-EpiBR on jasmonic acid (relative abundance) in the leaves of 30-day old plants of $B$. juncea grown in soil amended with $\mathrm{Cu}(\mathrm{II})$ solution before sowing.

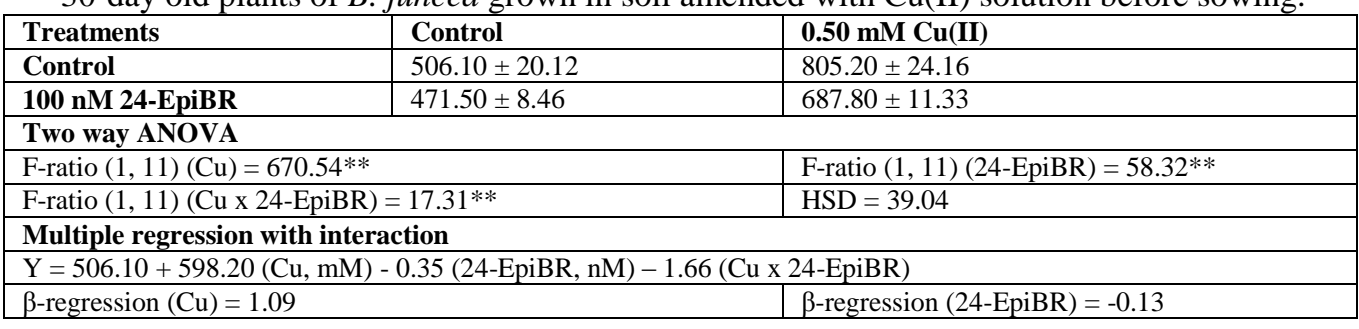




\begin{tabular}{|l|l|}
\hline$\beta$-regression $(\mathrm{Cu} \times 24-\mathrm{EpiBR})=-0.26$ & $\begin{array}{l}\text { Multiple correlation; \% variability explained }= \\
0.9947 * * * ; 98.94\end{array}$ \\
\hline Significant at: $* * \mathrm{P}<0.01, * * * \mathrm{P}<0.001, \mathrm{Y}=$ jasmonic acid (relative abundance) \\
\hline
\end{tabular}

Table 4. Effect of seed pre-soaking with 24-EpiBR on spermine (relative abundance) in the leaves of 30day old plants of $B$. juncea grown in soil amended with $\mathrm{Cu}(\mathrm{II})$ solution before sowing.

\begin{tabular}{|c|c|c|}
\hline Treatments & Control & $0.50 \mathrm{mM} \mathrm{Cu}(\mathrm{II})$ \\
\hline Control & $116.30 \pm 6.68$ & $251.10 \pm 9.42$ \\
\hline 100 nM 24-EpiBR & $126.20 \pm 13.77$ & $581.90 \pm 17.36$ \\
\hline \multicolumn{3}{|l|}{ Two way ANOVA } \\
\hline \multicolumn{2}{|c|}{ F-ratio $(1,11)(\mathrm{Cu})=1676.31 * *$} & F-ratio $(1,11)(24-E p i B R)=558.03 * *$ \\
\hline \multicolumn{2}{|c|}{ F-ratio $(1,11)(\mathrm{Cu} \times 24-\mathrm{EpiBR})=495.06 * *$} & $\mathrm{HSD}=28.29$ \\
\hline \multicolumn{3}{|c|}{ Multiple regression with interaction } \\
\hline \multicolumn{3}{|c|}{$\mathrm{Y}=116.30+269.60(\mathrm{Cu}, \mathrm{mM})+0.10(24-\mathrm{EpiBR}, \mathrm{nM})+6.42(\mathrm{Cu} \times 24-\mathrm{EpiBR})$} \\
\hline \multicolumn{2}{|c|}{$\beta$-regression $(\mathrm{Cu})=0.36$} & $\beta$-regression $(24-E p i B R)=0.03$ \\
\hline \multicolumn{2}{|c|}{$\beta$-regression $(\mathrm{Cu} \times 24-E p i B R)=0.74$} & $\begin{array}{l}\text { Multiple correlation; \% variability explained }= \\
0.9985^{* * * ; 99.70}\end{array}$ \\
\hline
\end{tabular}

Table 5. Effect of seed pre-soaking with 24-EpiBR on spermidine (relative abundance) in the leaves of 30-day old plants of $B$. juncea grown in soil amended with $\mathrm{Cu}(\mathrm{II})$ solution before sowing.

\begin{tabular}{|c|c|c|}
\hline Treatments & Control & $0.50 \mathrm{mM} \mathrm{Cu}(\mathrm{II})$ \\
\hline Control & $105.70 \pm 9.97$ & $200.50 \pm 12.52$ \\
\hline 100 nM 24-EpiBR & $141.00 \pm 9.74$ & $379.60 \pm 21.17$ \\
\hline \multicolumn{3}{|l|}{ Two way ANOVA } \\
\hline \multicolumn{2}{|c|}{ F-ratio $(1,11)(\mathrm{Cu})=417.31 * *$} & F-ratio $(1,11)(24-E p i B R)=172.58 * *$ \\
\hline \multicolumn{2}{|c|}{ F-ratio $(1,11)(\mathrm{Cu} \times 24-\mathrm{EpiBR})=77.63 * *$} & $\mathrm{HSD}=32.01$ \\
\hline \multicolumn{3}{|c|}{ Multiple regression with interaction } \\
\hline \multicolumn{3}{|c|}{$\mathrm{Y}=105.70+189.60(\mathrm{Cu}, \mathrm{mM})+0.35(24-\mathrm{EpiBR}, \mathrm{nM})+2.88(\mathrm{Cu} \times 24-E p i B R)$} \\
\hline \multicolumn{2}{|c|}{$\beta$-regression $(\mathrm{Cu})=0.45$} & $\beta$-regression $(24$-EpiBR) $=0.17$ \\
\hline \multicolumn{2}{|c|}{$\beta$-regression $(\mathrm{Cu} \times 24-\mathrm{EpiBR})=0.59$} & $\begin{array}{l}\text { Multiple correlation; } \% \text { variability explained }= \\
1 * * * ; 1\end{array}$ \\
\hline
\end{tabular}

Table 6. Effect of seed pre-soaking with 24-EpiBR on putrescine (relative abundance) in the leaves of 30day old plants of $B$. juncea grown in soil amended with $\mathrm{Cu}(\mathrm{II})$ solution before sowing.

\begin{tabular}{|c|c|c|}
\hline Treatments & Control & $0.50 \mathrm{mM} \mathrm{Cu}(\mathrm{II})$ \\
\hline Control & $922.10 \pm 39.82$ & $1355.70 \pm 149.04$ \\
\hline 100 nM 24-EpiBR & $1142.70 \pm 101.00$ & $1966.30 \pm 204.49$ \\
\hline \multicolumn{3}{|l|}{ Two way ANOVA } \\
\hline \multicolumn{2}{|c|}{ F-ratio $(1,11)(\mathrm{Cu})=62.54 * *$} & F-ratio $(1,11)(24-E p i B R)=27.34 * *$ \\
\hline \multicolumn{2}{|c|}{ F-ratio $(1,11)(\mathrm{Cu} \times 24-E p i B R)=6.02 *$} & $\mathrm{HSD}=311.83$ \\
\hline \multicolumn{3}{|c|}{ Multiple regression with interaction } \\
\hline \multicolumn{3}{|c|}{$\mathrm{Y}=922.10+867.20(\mathrm{Cu}, \mathrm{mM})+2.21(24-\mathrm{EpiBR}, \mathrm{nM})+7.80(\mathrm{Cu} \times 24-E p i B R)$} \\
\hline \multicolumn{2}{|c|}{$\beta$-regression $(\mathrm{Cu})=0.54$} & $\beta$-regression $(24-E p i B R)=0.27$ \\
\hline \multicolumn{2}{|c|}{$\beta$-regression $(\mathrm{Cu} \times 24-\mathrm{EpiBR})=0.42$} & $\begin{array}{l}\text { Multiple correlation; } \% \text { variability explained }= \\
0.9607 * * * ; 92.29\end{array}$ \\
\hline
\end{tabular}

Table 7. Effect of seed pre-soaking with 24-EpiBR on cadaverine (relative abundance) in the leaves of 30-day old plants of $B$. juncea grown in soil amended with $\mathrm{Cu}(\mathrm{II})$ solution before sowing.

\begin{tabular}{|c|c|c|}
\hline Treatments & Control & $0.50 \mathrm{mM} \mathrm{Cu}(\mathrm{II})$ \\
\hline Control & $1568.90 \pm 77.82$ & $3439.50 \pm 171.15$ \\
\hline $100 \mathrm{nM}$ 24-EpiBR & $1639.80 \pm 33.95$ & $5177.00 \pm 155.68$ \\
\hline \multicolumn{3}{|l|}{ Two way ANOVA } \\
\hline \multicolumn{2}{|c|}{ F-ratio $(1,11)(\mathrm{Cu})=1444.48^{* *}$} & F-ratio $(1,11)(24-E p i B R)=161.53 * *$ \\
\hline \multicolumn{2}{|c|}{ F-ratio $(1,11)(\mathrm{Cu} \times 24-E p i B R)=137.19 * *$} & $\mathrm{HSD}=279.10$ \\
\hline \multicolumn{3}{|c|}{ Multiple regression with interaction } \\
\hline \multicolumn{3}{|c|}{$\mathrm{Y}=1568.90+3741.20(\mathrm{Cu}, \mathrm{mM})+0.71(24-\mathrm{EpiBR}, \mathrm{nM})+33.33(\mathrm{Cu} \times 24-\mathrm{EpiBR})$} \\
\hline \multicolumn{2}{|c|}{$\beta$-regression $(\mathrm{Cu})=0.63$} & $\beta$-regression $(24$-EpiBR $)=0.02$ \\
\hline \multicolumn{2}{|c|}{$\beta$-regression $(\mathrm{Cu} \times 24-\mathrm{EpiBR})=0.48$} & $\begin{array}{l}\text { Multiple correlation; } \% \text { variability explained }= \\
0.9977 * * * ; 99.54\end{array}$ \\
\hline
\end{tabular}


Table 8. Effect of seed pre-soaking with 24-EpiBR on total sugars ( $\mathrm{mg} \mathrm{g}^{-1} \mathrm{FW}$ ) in the leaves of 30-day old plants of $B$. juncea grown in soil amended with $\mathrm{Cu}(\mathrm{II})$ solution before sowing.

\begin{tabular}{|c|c|c|c|c|}
\hline Treatments & Control & $0.25 \mathrm{mM} \mathrm{Cu}(\mathrm{II})$ & $0.50 \mathrm{mM} \mathrm{Cu}(\mathrm{II})$ & $0.75 \mathrm{mM} \mathrm{Cu}(\mathrm{II})$ \\
\hline Control & $1.36 \pm 0.076$ & $1.73 \pm 0.078$ & $2.12 \pm 0.044$ & $2.44 \pm 0.137$ \\
\hline 0.01 nM 24-EpiBR & $1.68 \pm 0.087$ & $1.93 \pm 0.106$ & $2.56 \pm 0.053$ & $2.65 \pm 0.036$ \\
\hline 1 nM 24-EpiBR & $1.70 \pm 0.056$ & $2.12 \pm 0.104$ & $2.61 \pm 0.062$ & $2.85 \pm 0.052$ \\
\hline 100 nM 24-EpiBR & $1.72 \pm 0.060$ & $2.28 \pm 0.072$ & $2.89 \pm 0.056$ & $2.99 \pm 0.026$ \\
\hline \multicolumn{5}{|l|}{ Two way ANOVA } \\
\hline \multicolumn{3}{|c|}{ F-ratio $(3,32)(\mathrm{Cu})=560.01 * *$} & \multicolumn{2}{|c|}{ F-ratio $(3,32)(24-E p i B R)=120.56^{* *}$} \\
\hline \multicolumn{3}{|c|}{ F-ratio $(9,32)(\mathrm{Cu} \times 24-$ EpiBR $)=3.93 * *$} & \multicolumn{2}{|l|}{$\mathrm{HSD}=0.10$} \\
\hline \multicolumn{5}{|c|}{ Multiple regression with interaction } \\
\hline \multicolumn{5}{|c|}{$\mathrm{Y}=1.59+1.48(\mathrm{Cu}, \mathrm{mM})+0.002(24-\mathrm{EpiBR}, \mathrm{nM})+0.003(\mathrm{Cu} \times 24-\mathrm{EpiBR})$} \\
\hline \multicolumn{3}{|c|}{$\beta$-regression $(\mathrm{Cu})=0.84$} & \multicolumn{2}{|c|}{$\beta$-regression (24-EpiBR) $=0.19$} \\
\hline \multicolumn{3}{|c|}{$\beta$-regression $(\mathrm{Cu} \times 24-\mathrm{EpiBR})=0.13$} & \multicolumn{2}{|c|}{$\begin{array}{l}\text { Multiple correlation; \% variability explained }= \\
0.9348 * * * ; 87.39\end{array}$} \\
\hline
\end{tabular}

Table 9. Effect of seed pre-soaking with 24-EpiBR on reducing sugars ( $\mathrm{mg} \mathrm{g}^{-1} \mathrm{FW}$ ) in the leaves of 30day old plants of $B$. juncea grown in soil amended with $\mathrm{Cu}(\mathrm{II})$ solution before sowing.

\begin{tabular}{|c|c|c|c|c|}
\hline Treatments & Control & $0.25 \mathrm{mM} \mathrm{Cu}(\mathrm{II})$ & $0.50 \mathrm{mM} \mathrm{Cu}(\mathrm{II})$ & $0.75 \mathrm{mM} \mathrm{Cu}(\mathrm{II})$ \\
\hline Control & $1.16 \pm 0.066$ & $1.29 \pm 0.036$ & $1.38 \pm 0.046$ & $1.40 \pm 0.036$ \\
\hline 0.01 nM 24-EpiBR & $1.32 \pm 0.079$ & $1.39 \pm 0.053$ & $1.48 \pm 0.020$ & $1.45 \pm 0.082$ \\
\hline 1 nM 24-EpiBR & $1.34 \pm 0.056$ & $1.44 \pm 0.020$ & $1.53 \pm 0.072$ & $1.48 \pm 0.044$ \\
\hline 100 nM 24-EpiBR & $1.35 \pm 0.066$ & $1.51 \pm 0.076$ & $1.60 \pm 0.020$ & $1.57 \pm 0.122$ \\
\hline \multicolumn{5}{|l|}{ Two way ANOVA } \\
\hline \multicolumn{3}{|c|}{ F-ratio $(3,32)(\mathrm{Cu})=26.68^{* *}$} & \multicolumn{2}{|c|}{ F-ratio $(3,32)(24-E p i B R)=22.20 * *$} \\
\hline \multicolumn{2}{|c|}{ F-ratio $(9,32)(\mathrm{Cu} \times 24$-EpiBR $)=0.52$} & & \multicolumn{2}{|c|}{$\mathrm{HSD}=0.08$} \\
\hline \multicolumn{5}{|c|}{ Multiple regression with interaction } \\
\hline \multicolumn{5}{|c|}{$\mathrm{Y}=1.30+0.24(\mathrm{Cu}, \mathrm{mM})+0.001(24-\mathrm{EpiBR}, \mathrm{nM})+0.001(\mathrm{Cu} \times 24-\mathrm{EpiBR})$} \\
\hline \multicolumn{3}{|c|}{$\beta$-regression $(\mathrm{Cu})=0.61$} & \multicolumn{2}{|c|}{$\beta$-regression $(24-E p i B R)=0.39$} \\
\hline \multicolumn{3}{|c|}{$\beta$-regression $(\mathrm{Cu} \times 24-\mathrm{EpiBR})=0.12$} & \multicolumn{2}{|c|}{$\begin{array}{l}\text { Multiple correlation; } \% \text { variability explained }= \\
0.8073^{* * *} ; 65.17\end{array}$} \\
\hline
\end{tabular}
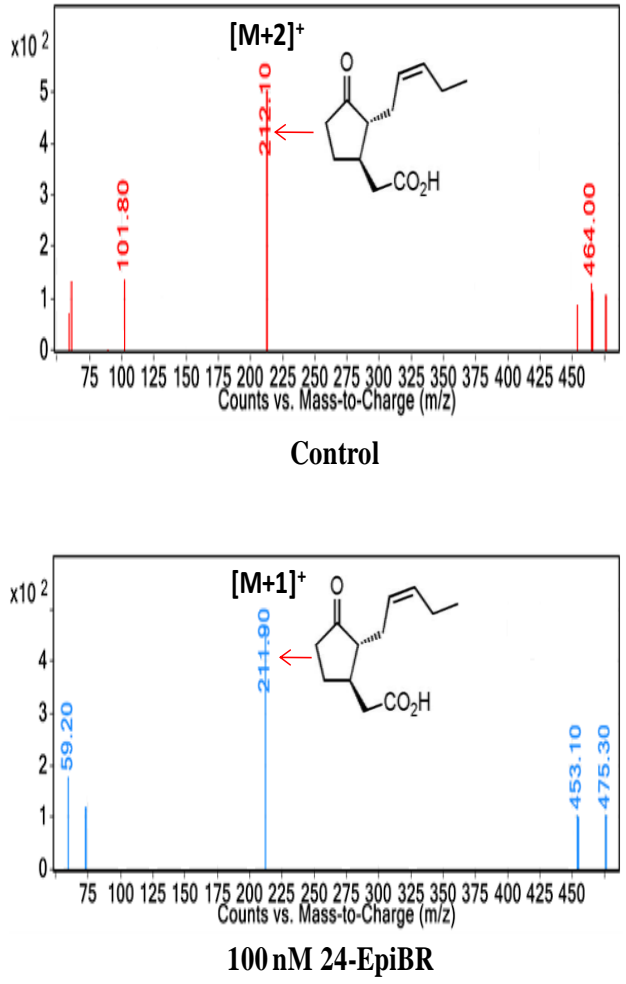
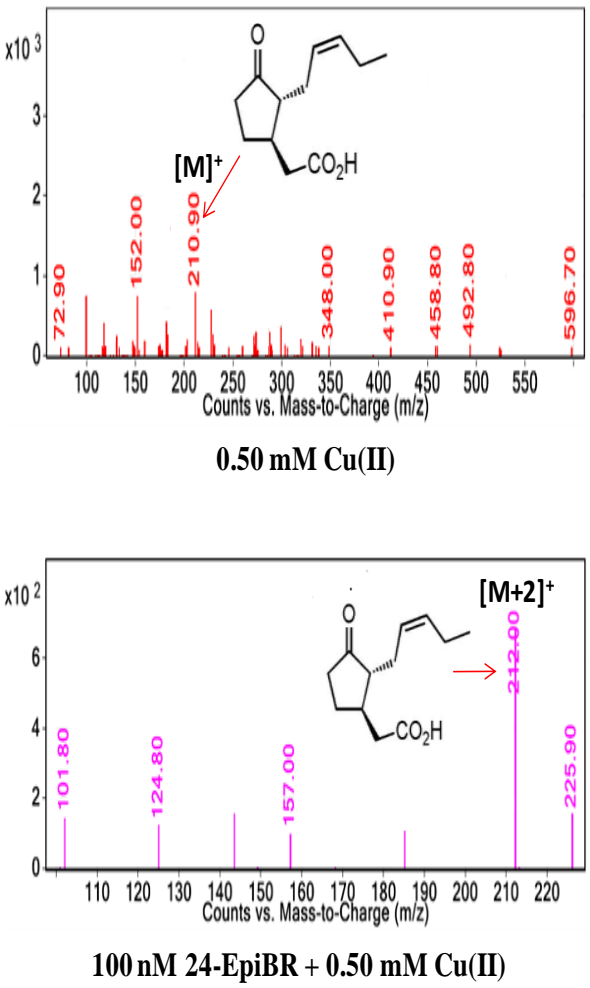

Fig. 1. Effect of seed pre-soaking with 24-EpiBR on jasmonic acid (relative abundance) in the leaves of 30-day old plants of B. juncea grown in soil amended with $\mathrm{Cu}(\mathrm{II})$ solution before sowing. 

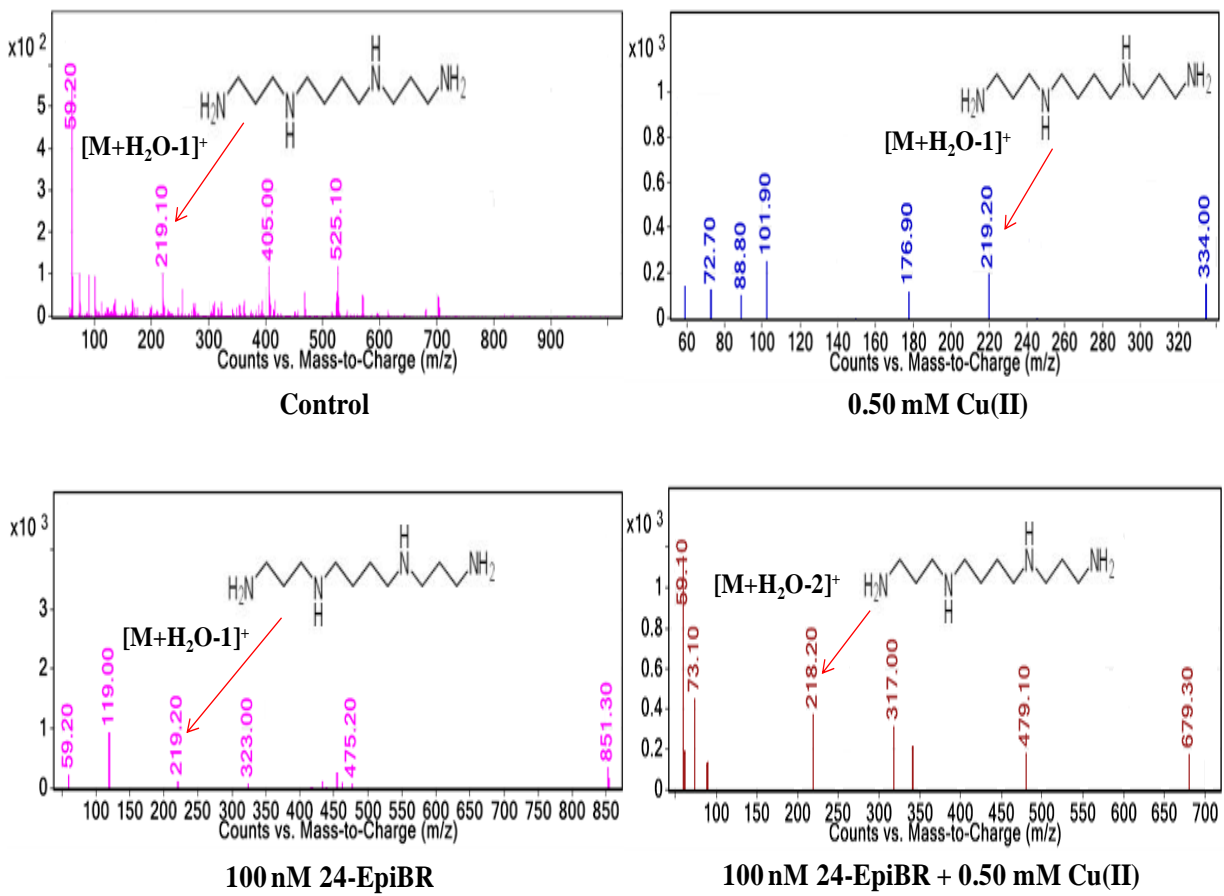

Fig. 2. Effect of seed pre-soaking with 24-EpiBR on spermine (relative abundance) in the leaves of 30-day old plants of $B$. juncea grown in soil amended with $\mathrm{Cu}$ (II) solution before sowing.
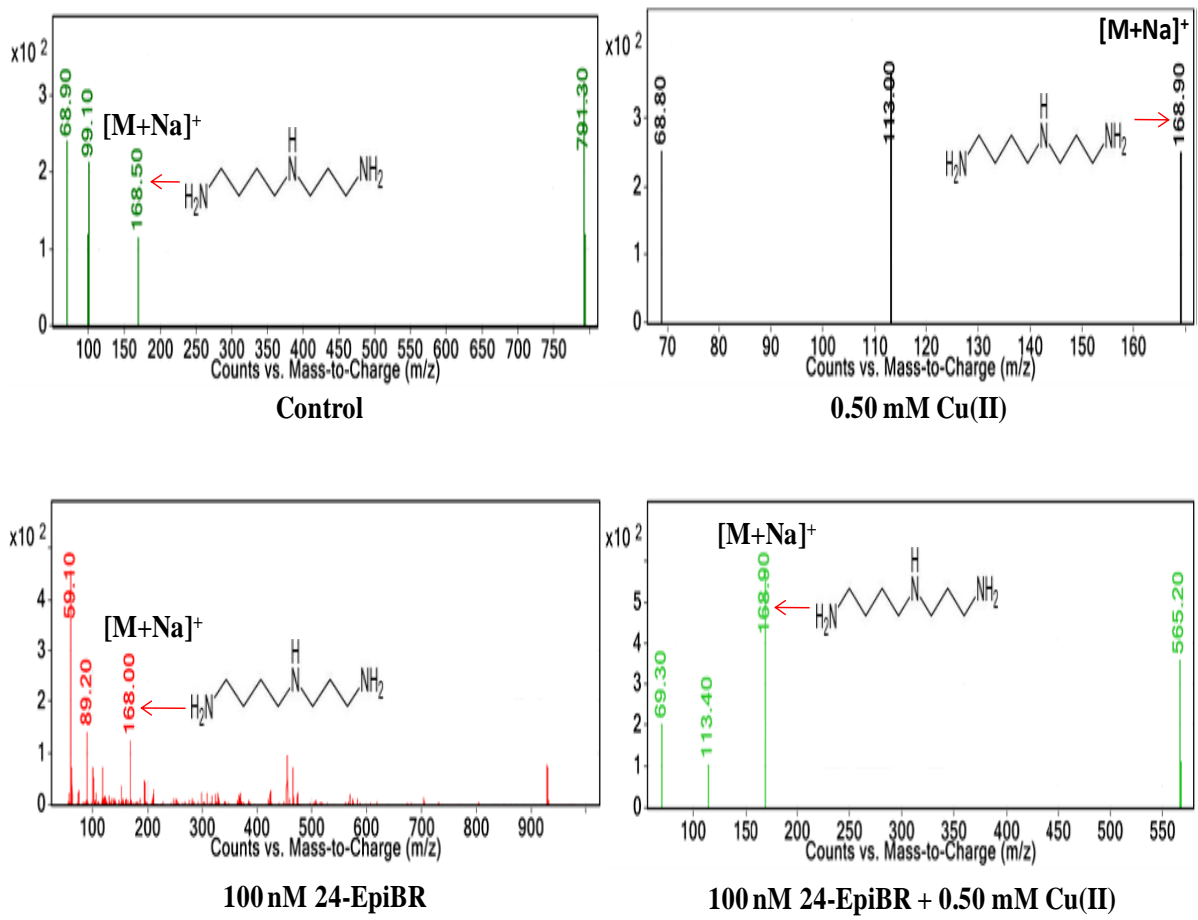

Fig. 3. Effect of seed pre-soaking with 24-EpiBR on spermidine (relative abundance) in the leaves of 30-day old plants of $B$. juncea grown in soil amended with $\mathrm{Cu}(\mathrm{II})$ solution before sowing. 

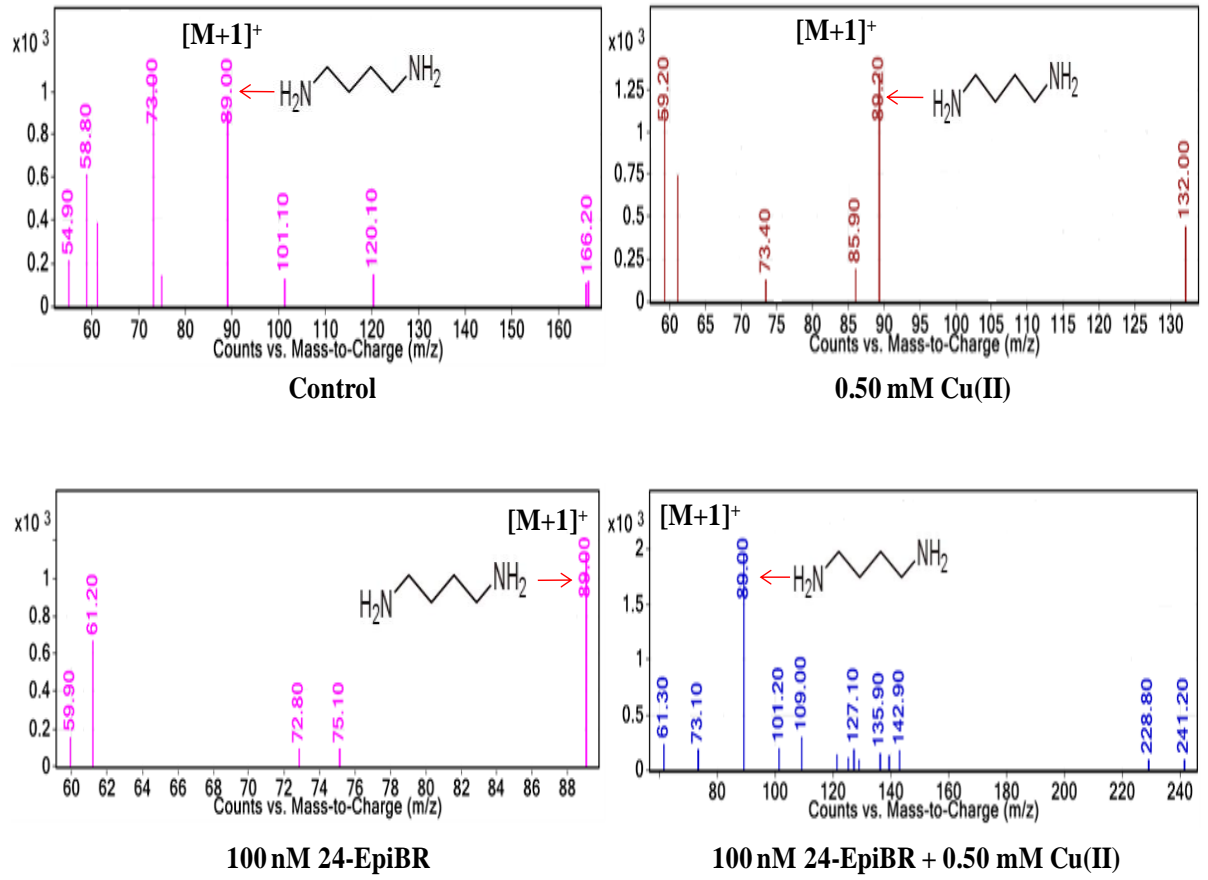

Fig. 4. Effect of seed pre-soaking with 24-EpiBR on putrescine (relative abundance) in the leaves of 30-day old plants of $B$. juncea grown in soil amended with $\mathrm{Cu}(\mathrm{II})$ solution before sowing.
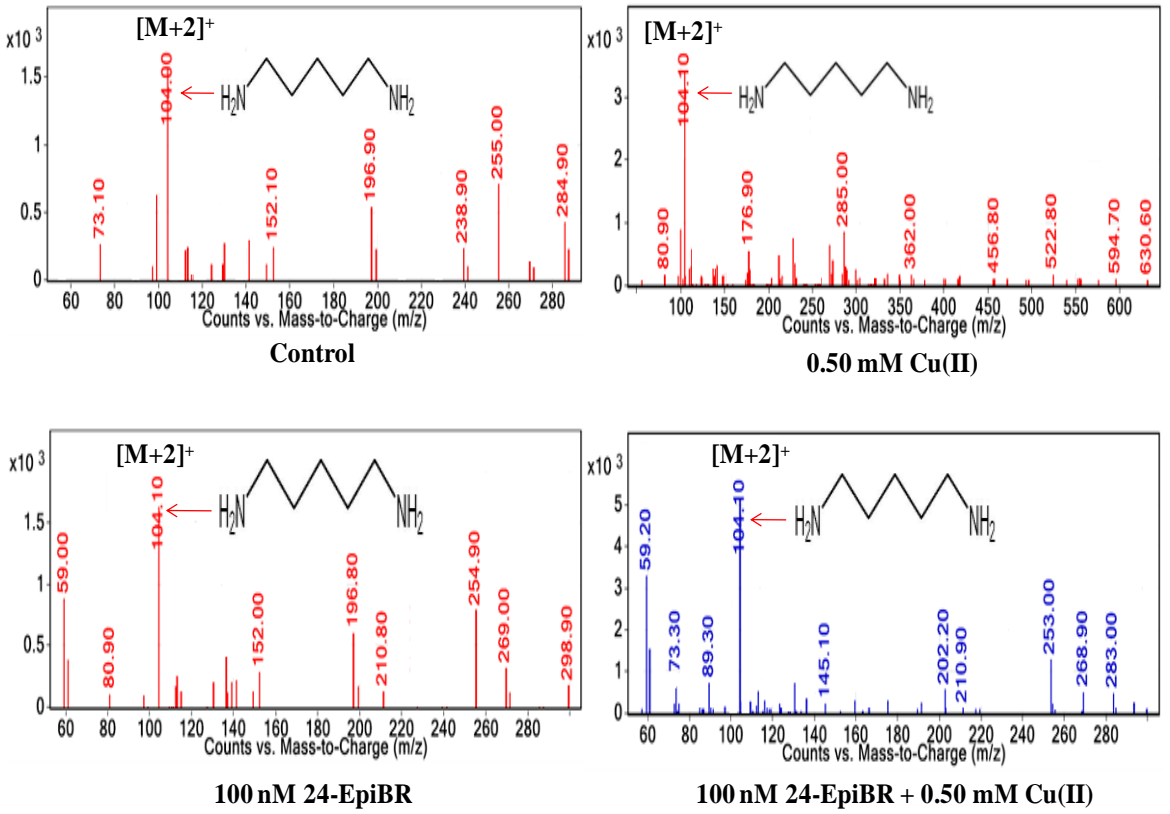

Fig. 5. Effect of seed pre-soaking with 24-EpiBR on cadaverine (relative abundance) in the leaves of 30-day old plants of $B$. juncea grown in soil amended with $\mathrm{Cu}(\mathrm{II})$ solution before sowing.

\section{Conclusion}

$\mathrm{Cu}$ (II) influences a number of metabolic processes in plants and results in a reduction of shoot and root lengths of $B$. juncea plants. Sugars and PAs play a number of protective functions in plants and elevation in their contents under $\mathrm{Cu}$ (II) treatment is an adaptive strategy of plants to overcome the stress. 24-EpiBR seed presoaking treatment mitigated the stress produced by $\mathrm{Cu}$ (II) in B. juncea plants. 24-EpiBR influenced the endogenous levels of sugars, jasmonic acid and PAs in the plants and helped in maintaining plant homeostasis alone and in binary combination with $\mathrm{Cu}$ (II). The inhibitory action of jasmonic acid on plant growth is negatively regulated by 24-EpiBR. 24-EpiBR and PAs showed a positive interaction and the increase in the PAs further induced a positive effect on sugars contents and made the plants more tolerant to stress conditions. 


\section{Acknowledgement}

Financial assistance from Department of Science and Technology (DST), Ministry of Science and Technology, Government of India, New Delhi, India is duly acknowledged.

\section{References}

[1]. R. Hansch, and R. R. Mendel, Physiological functions of mineral micronutrients (Cu, Zn, Mn, Fe, Ni, Mo, B, Cl). Current Opinion in Plant Biology, 2009, 12, 259-266.

[2]. E.Morelli, and G. Scarano, Copper-induced changes of non-protein thiols and antioxidant enzymes in the marine microalga Phaeodactylum tricornutum. Plant Science, 2004, 167, 289-296.

[3]. L.Brahim, and M. Mohamed, Effects of copper stress on antioxidative enzymes, chlorophyll and protein content in Atriplex halimus. African Journal of Biotechnology, 2011, 10, 10143-10148.

[4]. S.K. Panda, I. Chaudhury, and M. H. Khan, Heavy metals induce lipid peroxidation and affect antioxidants in wheat leaves. Biologia Plantarum, 2003, 46, 289-294.

[5]. S. P. Choudhary, R. Bhardwaj, B. D. Gupta, P. Dutt, R. K. Gupta, S. Biondi, and M. Kanwar, Epibrassinolide induces changes in indole-3-acetic acid, abscisic acid and polyamine concentrations and enhances antioxidant potential of radish seedlings under copper stress. Physiologia Plantarum. 2010, 140, 280-296.

[6]. S. D. Clouse, Brassinosteroid signal transduction: from receptor kinase activation to transcriptional networks regulating plant development. Plant Cell. 2011, 23, 1219-1230.

[7]. R. Nishiyama, Y. Watanabe, Y. Fujita, D. T. Le, M. Kojima, T. Werner, R. Vankova, K. Yamaguchi-Shinozaki, K. Shinozaki, T. Kakimoto, H. Sakakibara, T. Schmulling, and L. S. Tran, Analysis of cytokinin mutants and regulation of cytokinin metabolic genes reveals important regulatory roles of cytokinins in drought, salt and abscisic acid responses, and abscisic acid biosynthesis. Plant Cell, 2011, 23, 2169-2183.

[8]. S. Kagale, U. K. Divi, J. E. Krochko, W. A. Keller, and P. Krishna, Brassinosteroid confers tolerance in Arabidopsis thaliana and Brassica napus to a range of abiotic stresses. Planta, 2007, 225, 353-364

[9]. U. K. Divi, T. Rahman, and P. Krishna, Brassinosteroid-mediated stress tolerance in Arabidopsis shows interactions with abscisic acid, ethylene and salicylic acid pathways. BMC Plant Biology, 2010, 10, 151. doi:10.1186/1471-2229-10-151.

[10]. H. Nayyar, and S. Chander, Protective effects of polyamines against oxidative stress induced by water and cold stress in chickpea. Journal of Agronomy and Crop Science, 2004, 190, 355-365.

[11]. X. P. Wen, Y. Ban, H. Inoue, N. Matsuda, and T. Moriguchi, Spermidine levels are implicated in heavy metal tolerance in a spermidine synthase overex- pressing transgenic European pear by exerting antioxidant activities. Transgenic Research, 2010, 19, 91-103.

[12]. M. H. Hou, S. B. Lin, J. M. Yuann, W. C. Lin, A. H. J. Wang, and L. S. Kan, Effects of polyamines on the thermal stability and formation kinetics of DNA duplexes with abnormal sequence. Nucleic Acids Research, 2001, 29, 5121-5128.

[13]. A. Tassoni, F. Antognoni, M. L. Baltistini, O. Sanvido, and N. Bagni, 1998. Characterization of spermidine binding to solubilised plasma membrane proteins from zucchini hypocotyls. Plant Physiology, 1998, 117, 971-977.

[14]. K. Banerjee, and S. Kulkarni, Agilent 6530 accurate-mass Q-TOF LC/MS system with agilent 1290 infinity LC for multi plant growth regulator analysis from grapes. Agilent Technologies, Inc., USA, 2011, 5990-7185EN.

[15]. M. Dubois, K. A. Gilles, J. K. Hamilton, P. A. Rebers, and F. Smith, Colorimetric method for determination of sugars and related substances. Analytical Chemistry, 1956, 28, 350-356

[16]. N. Nelson, A photometric adaptation of the Somogyi method for the determination of glucose. The Journal of Biological Chemistry, 1994, 153, 375-380.

[17]. P. Schopfer, Hydrogen peroxide-mediated cell-wall stiffening in vitro in maize coleoptiles. Planta, 1996, 199, 43-49.

[18]. M. P. Gonzalez-Garcia, J. Vilarrasa-Blasi, M. Zhiponova, F. Divol, S. Mora-Garcia, E. Russinova, and Al. Cano-Delgado, Brassinosteroids control meristem size by promoting cell cycle progression in Arabidopsis roots. Development, 2011, 138, 849-859

[19]. R. Rakwal, S. Tomogami, G. K. Agrawal, and H. Iwahashi, Octadecanoid signaling component "burst" in rice (Oryza sativa L.) seedling leaves upon wounding by cut and treatment with fungal elicitor chitosan. Biochemical and Biophysical Research Communications, 2002, 295, 1041-1045

[20]. H. Weber, Fatty acid-derived signals in plants. Trends in Plant Science, 2002, 7, 217-224.

[21]. A. G. Ivanov, and M. I. Kicheva, Chlorophyll fluorescence properties of chloroplast membranes isolated from jasmonic acid-treated barley seedlings. Journal of Plant Physiology, 1993, 141, 410-414.

[22]. W. Maksymiec, and Z. Krupa, Jasmonic acid and heavy metals in Arabidopsis plants - a similar physiological response to both stressors. Journal of Plant Physiology, 2002, 159, 509-515

[23]. G. Merkouropoulos, and A. H. Shirsat, The unusual Arabidopsis extensin gene stExt1 is expressed throughout plant development and is induced by variety biotic and abiotic stresses. Planta, 2003, 217, 356-366

[24]. A. Swiatek, M. Lenjou, D. Van Bockstaele, D. Inze, and H. Van Onckelen, Differential effect of jasmonic acid and abscisic acid on cell cycle progression in tobacco BY-2 cells. Plant Physiology, 2002, 128, 201-211.

[25]. R. Rakwal, S. Tomogami, and O. Kodama, Role of jasmonic acid as a signalling molecule in copper chloride-elicited rice phytoalexein production. Bioscience, Biotechnology and Biochemistry, 1996, 60, 1046-1048.

[26]. C, Ren, C. Han, W. Peng, Y. Huang, Z. Peng, X. Xiong, Q. Zhu, B. Gao, and D. Xie, A leaky mutation in DWARF4 reveals an antagonistic role of brassinosteroid in the inhibition of root growth by jasmonate in Arabidopsis. Plant Physiology, 2009, 151, $1412-1420$.

[27]. A. K. Papadakis, and K. A. Roubelakis-Angelakis, Polyamines inhibit NADPH oxidase-mediated superoxides generation and putrescine prevents programmed cell death induced by polyamine oxidase-generated hydrogen peroxide. Planta, 2005, 220, 826837.

[28]. N. D. Young, and A. W. Galston, Putrescine and acid stress: Induction of arginine decarboxylase activity and putrescine accumulation by low pH. Plant Physiology, 1983, 71, 767-771.

[29]. A. A. Aly, and A. A. Mohamed, The impact of copper ion on growth, thiol compounds and lipid peroxidation in two maize cultivars (Zea mays L.) grown in vitro, Australian Journal of Crop Science, 2012, 6, 541-549.

[30]. A. B. Samarakoon, and W. E. Rauser, Carbohydrate levels and photoassimiilate export from leaves of Phaseolus vulgaris exposed to excess cobalt, nickel, and zinc. Plant Physiology, 1979, 63, 1165-1169.

[31]. R. S. Dubey, and A. K. Singh, Salinity induces accumulation of soluble sugars and alters the activity of sugar metabolizing enzymes in rice plants. Biologia Plantarum, 1999, 42, 233-239. 
[32]. B. V. Vardhini, E. Sujatha, and S. S. R. Rao, Influence of brassinosteroids on metabolites of Raphanus sativus L. Journal of Phytology, 2012, 4, 45-47.

[33]. M. Khorshidi, A. Kousha, and M. Alemi, Effect of putrescine on MDA, proline and sugars in Matricaria chamomilla. International Journal of Farming and Allied Sciences, 2013, 2, 607-611.

[34]. I. M. Zeid, and Z. A. Shedeed, Response of alfalfa to putrescine treatment under drought stress. Biologia Plantarum, 2006, 50, 635640 . 